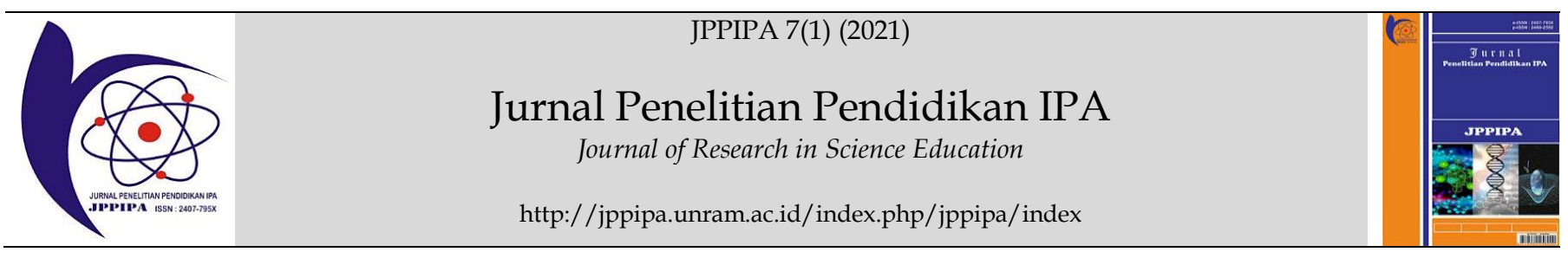

\title{
Synthesis of Tin Oxide Thin Layer by Doping Aluminum, Fluorine, and Indium Using Sol-Gel Spin Coating Technique
}

\author{
Aris Doyan ${ }^{1,2^{*}}$, Susilawati $^{1,2}$, Lalu Muliyadi ${ }^{2}$ \\ ${ }^{1}$ Physics Education, Faculty of Teacher Training and Education, University of Mataram, Lombok, West Nusa Tenggara, Indonesia. \\ ${ }^{2}$ Master of Science Education Program, University of Mataram, Lombok, West Nusa Tenggara, Indonesia.
}

DOI: $\underline{10.29303 / \text { jppipa.v7i1.468 }}$

\section{Article Info}

Received: September $28^{\text {th }}, 2020$

Revised: Oktober $25^{\text {th }}, 2020$

Accepted: November 17th, 2020

\begin{abstract}
The synthesis of tin oxide thin films with doping aluminum, fluorine, and indium $(\mathrm{SnO} 2: \mathrm{Al}+\mathrm{F}+\mathrm{In}$ ) by sol-gel spin coating technique has been successfully carried out. This synthesis aims to determine the quality of the thin film formed by adding doping aluminum, fluorine, and indium. The basic material used is $\mathrm{SnCl}_{2} \cdot 2 \mathrm{H}_{2} \mathrm{O}$, while the doping material used is $\mathrm{AlCl}_{3}, \mathrm{NH}_{4} \mathrm{~F}$, and $\mathrm{InCl}_{3} .4 \mathrm{H}_{2} \mathrm{O}$. The comparison of the basic ingredients and doping mixture of aluminum, fluorine and indium $\left(\mathrm{SnO}_{2}: \mathrm{Al}+\mathrm{F}+\mathrm{In}\right)$ used were 100: 0\%, 95: 5\%, $90: 10 \%, 85: 15 \%, 80: 20 \%$ and $75: 25 \%$. The synthesis uses a glass substrate with size (10 x $10 \times 3) \mathrm{mm}$. Coating synthesis includes substrate preparation, sol-gel making, film making, and sample heating. The layers that are made consist of 1 to 4 layers. The results showed that the layer formed had a high degree of transparency along with the increasing concentration of the doping material percentage. The higher the doping concentrations of aluminum, fluorine, and indium, the higher the transparency of the resulting layer. Besides, the greater the number of layers, the lower the transparency level of the layers.
\end{abstract}

Keywords: Thin layer; $\mathrm{SnO}_{2}$; aluminum; fluorine; indium; sol-gel; spin coating.

Citation: Doyan, A., Susilawati, S., \& Muliyadi, L. (2020). Synthesis of Tin Oxide Thin Layer by Doping Aluminum, Fluorine, and Indium Using Sol-Gel Spin Coating Technique. Jurnal Penelitian Pendidikan IPA, 7(1), 11-14. doi:https://doi.org/10.29303/jppipa.v7i1.468

\section{Introduction}

Tin oxide $\left(\mathrm{SnO}_{2}\right)$ is a semiconductor material that has unique characteristics with low resistivity, high optical transparency, and has an energy bandgap of about $3.6 \mathrm{eV}$ (Doyan et al, 2017). $\mathrm{SnO}_{2}$ is widely applied to transistors (Liu et al, 2020), diodes (Gullu et al, 2020), capacitors (Doyan et al, 2018), liquid crystal displays (Andrade et al, 2019), solar cells (Bittau et al, 2017), and other optoelectronic equipment (Ikraman et al, 2017). Also, $\mathrm{SnO}_{2}$ is widely applied as a gas sensor (Rebholz et al, 2015) because it is very sensitive to gas (Susilawati et al, 2020).

The characteristics of $\mathrm{SnO}_{2}$ can be modified as needed by adding another element called dopant (Ikraman et al, 2017). $\mathrm{SnO}_{2}$ is usually doped with aluminum (Imawanti et al, 2017), fluorine (Kendall et al, 2020), and indium (Hakim et al, 2019), zinc (Hegazy et al, 2019), and antimony (Khorshidi et al, 2019) . Also, $\mathrm{SnO}_{2}$ can be doped with a mixture of aluminum and zinc (Doyan et al, 2018), a mixture of antimony and zinc (Medhi et al, 2019), a mixture of aluminum and fluorine (Susilawati et al, 2020), and a mixture of aluminum and indium (Munandar et al, 2020).

The characteristics of $\mathrm{SnO}_{2}$ itself can be influenced by doping aluminum, fluorine, and indium, which is called doping which can stabilize the particles and change the energy bandgap that $\mathrm{SnO}_{2}$ has. Besides, doping with this material is known to change the structure, increase the response, selectivity and stability of the gas sensor, increase electrical conductivity and optical transmission, and can reduce the energy band gap of $\mathrm{SnO}_{2}$ (Muliyadi et al, 2019). However, it is not yet known how the combined effect of these three dopants on the characteristics of the $\mathrm{SnO}_{2}$ thin layer itself, so that further investigation is needed regarding 
the effect of the three dopants on the characteristics of the $\mathrm{SnO}_{2}$ layer.

\section{Method}

The basic material used in this study is $\mathrm{SnCl}_{2} \cdot 2 \mathrm{H}_{2} \mathrm{O}$. Doping materials use Aluminum Chloride $\left(\mathrm{AlCl}_{3}\right)$, Ammonium Fluoride $\left(\mathrm{NH}_{4} \mathrm{~F}\right)$, and Indium (III) Chloride $\left(\mathrm{InCl}_{3} \cdot 4 \mathrm{H}_{2} \mathrm{O}\right)$. The solvent used is ethanol $\left(\mathrm{C}_{2} \mathrm{H}_{5} \mathrm{OH}\right)$. The substrate used is glass with size (10x10x3) $\mathrm{mm}$. The synthesis of thin films includes substrate preparation, sol-gel manufacture, thin-film manufacture, and heating processes (Muliyadi et al, 2019).

The sol-gel preparation uses doping variations $(0,5,10,15,20$, and 25$) \%$ which are dissolved in ethanol using a magnetic stirring at room temperature. After that, the sol solution was left to stand for 48 hours. The next process is making a thin layer using a spin coater at a speed of $2000 \mathrm{rpm}$ for 3 minutes. After that, the sample is heated in a furnice at a temperature of $150{ }^{\circ} \mathrm{C}$ for one hour (Susilawati et al, 2019).

\section{Result and Discussion}

Synthesis of $\mathrm{SnO}_{2}$ thin films with doping mixture of aluminum, fluorine, and indium $\left(\mathrm{SnO}_{2}: \mathrm{Al}+\mathrm{F}+\mathrm{In}\right)$ using the sol-gel spin coating method. The basic material used is $\mathrm{SnCl}_{2} .2 \mathrm{H}_{2} \mathrm{O}$ as tin oxide $\left(\mathrm{SnO}_{2}\right)$, while the doping materials used are $\mathrm{AlCl}_{3}, \mathrm{NH}_{4} \mathrm{~F}$, and $\mathrm{InCl}_{3} .4 \mathrm{H}_{2} \mathrm{O}$ as aluminum, fluorine, and indium. The comparison of the basic ingredients and doping mixture of aluminum, fluorine and indium $\left(\mathrm{SnO}_{2}\right.$ : $\mathrm{Al}+\mathrm{F}+\mathrm{In}$ ) used were 100: 0\%, 95: 5\%, 90: 10\%, 85: 15\%, 80: $20 \%$, and $75: 25 \%$. The synthesis of this thin layer uses glass with a size $(10 \times 10 \times 3) \mathrm{mm}$ as a substrate.

This synthesis stage includes the preparation of the glass substrate, making sol-gel, making thin films, and the process of heating the thin films. Substrate preparation is done by washing the glass substrate with detergent then cleaning it with alcohol and drying it in an oven. This preparation aims to remove the remnants of dirt attached to the glass substrate (Muliyadi et al, 2019).

The next process is to make a sol-gel with a variety of doping materials for aluminum, fluorine, and indium, then dissolve it with ethanol using a magnetic stirring so that the solution is quickly homogeneous and becomes a sol. After the solution is homogeneous, then the solution is allowed to stand for 48 hours at room temperature so that it becomes a gel. The sol that is formed is shown in Figure 1.

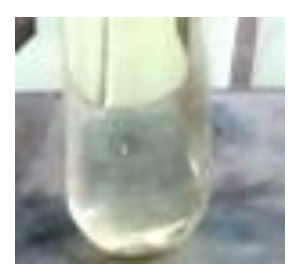

(a)

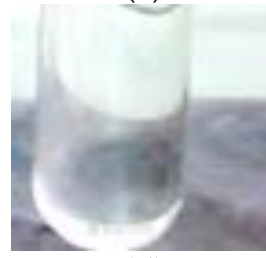

(d)

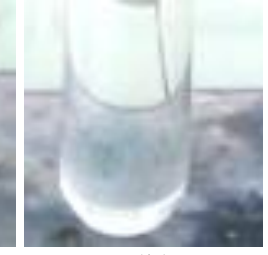

(b)

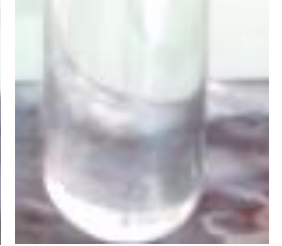

(e)

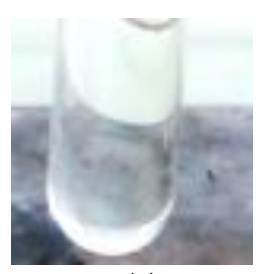

(c)

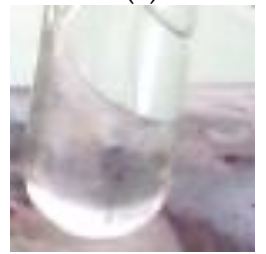

(f)
Figure 1. Sol SnO2: $\mathrm{Al}+\mathrm{F}+\mathrm{In}$. (a) 100: $0 \%$, (b) $95: 5 \%$, (c) 90 : $10 \%$, (d) $85: 15 \%$, (e) $80: 20 \%$, (f) $75: 25 \%$.

Based on Figure 1, it is clear that the level of transparency of the resulting sol is higher as the amount of doping of aluminum, fluorine, and indium increases. This is because the reaction of $\mathrm{SnCl}_{2}$ with ethanol is reduced by the addition of aluminum, fluorine, and indium dopants (Muliyadi et al, 2019).

The next process is to make a thin layer using a spin coater that is rotated at $2000 \mathrm{rpm}$ for 3 minutes. After that, the sample is heated in a furnace at a temperature of $150^{\circ} \mathrm{C}$ for one hour.

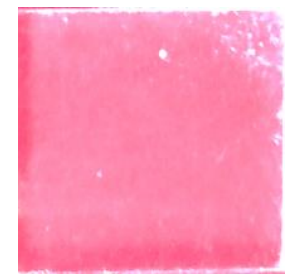

(a)

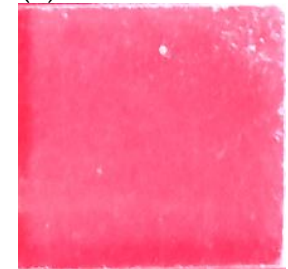

(d)

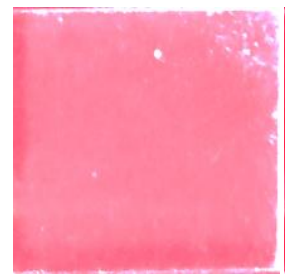

(b)

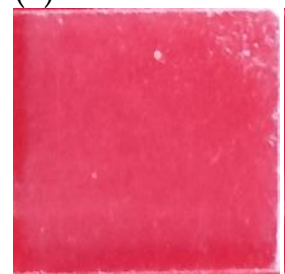

(e)

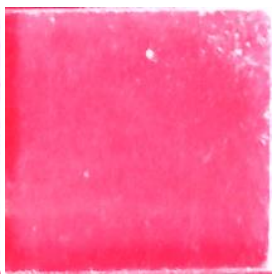

(c)

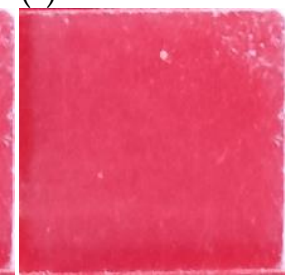

(f)
Figure 2. $\mathrm{SnO}_{2}: \mathrm{Al}+\mathrm{F}+\mathrm{In}$ thin layer (a) 100: 0\%, (b) 95: 5\%, (c) 90: $10 \%$, (d) $85: 15 \%$, (e) $80: 20 \%$, (f) $75: 25 \%$.

Figure 2 shows a thin layer of $\mathrm{SnO}_{2}$ with doping variations of aluminum, fluorine, and indium. The addition of doping aluminum, fluorine, and indium resulted in a change in the transparency of the thin layer (Muliyadi et al, 2019). The level of transparency of the layers formed is greater with the increasing doping concentrations of aluminum, fluorine, and indium (Susilawati et al, 2019). 


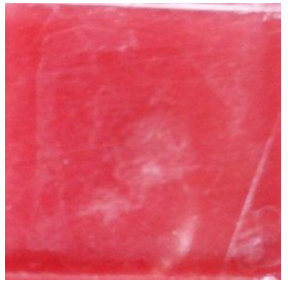

(a)

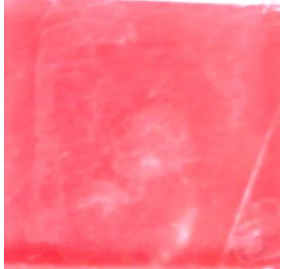

(c)

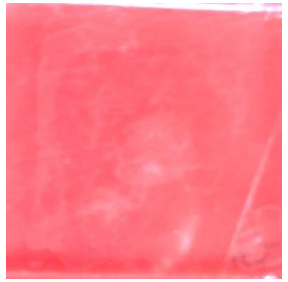

(b)

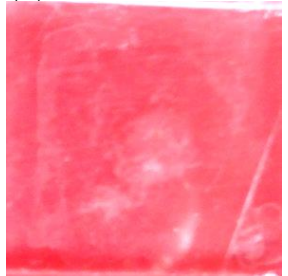

(d)

Figure 3. Thin-film $\mathrm{SnO}_{2}$ : $\mathrm{Al}+\mathrm{F}+\mathrm{In}$ layer variation. (a) 1 layer, (b) 2 layers, (3) 3 layers, (d) 4 layers.

Figure 3 shows that the sample of the thin layer $\mathrm{SnO}_{2}: \mathrm{Al}+\mathrm{F}+\mathrm{In}$ layer variation. The greater the number of layers, the more opaque the layer formed. This means that the transparency level of the layer is getting lower. This is because the grain size of the layers is getting bigger as the number of layers increases (Muliyadi et al, 2019).

\section{Conclusion}

The synthesis of $\mathrm{SnO}_{2}$ thin films with doping aluminum, fluorine, and indium $\left(\mathrm{SnO}_{2}: \mathrm{Al}+\mathrm{F}+\mathrm{In}\right)$ using the sol-gel spin coating technique has been successfully carried out. The results showed that the layer formed had a high degree of transparency along with the increasing concentration of the doping substance percentage. The higher the doping concentrations of aluminum, fluorine, and indium, the higher the transparency of the coating. The greater the number of layers, the more opaque the layer formed. This means that the transparency level of the layer is getting lower.

\section{Acknowledgements}

Thanks to all those who have helped to materialize this article and this research has been funded by the Ministry of Research, Technology, and Higher Education's superior research grant for the 2020 budget year. Input and critical review to improve this paper.

\section{References}

Andrade, D.F., Fortunato, F.M., \& Pereira-Filho, E.R. (2019). Calibration Strategies for Determination of the in Content in Discarded Liquid Crystal Displays (LCD) from Mobile Phones Using

Laser-Induced Breakdown Spectroscopy (LIBS). Analytica Chimica Acta, 1061，42-49. DOI:10.1016/j.aca.2019.02.038.

Bittau, F., Abbas, A., Barth, K.L., Bowers, J.W., \& Walls, J.M. (2017). The Effect of Temperature on Resistive $\mathrm{ZnO}$ Layers and the Performance of Thin Film CdTe Solar Cells. Thin Solid Films, 633, 92-96.

Doyan, A., Susilawati, Imawanti, Y.D. Gunawan, E.R. \& Taufik, M. (2017). Characterization Thin Film Nano Particle Of Aluminum Tin Oxide (AITO) as Touch Screen. Journal of Physics, 1097, 1-9.

Doyan, A., Susilawati \& Imawanti, Y.D. (2017). Synthesis and Characterization of $\mathrm{SnO}_{2}$ thin layer with a doping Aluminum is deposited on Quartz Substrates. American Institute of Physics, 1801, 1-7.

Doyan, A., Susilawati, Fitri, S.A. \& Ahzan, S. (2017). Cristal Structure Charaterization of Thin Layer Zinc Oxide. Materials Science and Engineering, 196, $1-6$.

Doyan, A., \& Humaini. 2017. Sifat Optik Lapisan Tipis ZnO. Jurnal Pendidikan Fisika dan Teknologi, 3(1), 34-39.

Doyan, A., Susilawati, Ikraman, N., \& Taufik, M. (2018). Characterization of $\mathrm{SnO}_{2}$ Film with $\mathrm{Al}-\mathrm{Zn}$ Doping Using Sol-Gel Dip Coating Techniques. Journal of Physics, 1011, 1-6. DOI:10.1088/17426596/1011/1/012015.

Doyan, A., Susilawati, Hakim, S., Muliyadi, L., \& Taufik, M. (2019). The Effect of Indium Doped $\mathrm{SnO}_{2}$ Thin Films on Optical Properties Prepared by Sol-Gel Spin Coating Technique. Journal of Physics: Conference Series, 1397 (012005), 1-8. DOI:10.1088/1742-6596/1397/1/012005.

Doyan, A., Susilawati, Hakim, S., Muliyadi, L., \& Taufik, M. 2020. The Effect of Annealing Temperature Thin Films Indium Doped $\mathrm{SnO}_{2}$ to Optics Properties and Material Composition. Journal of Physics: Conference Series, 1572 (012072), 1-8. DOI:1088/1742-6596/1572/1/012072.

Doyan, A., Susilawati, Harjono, A., Azzahra, S., \& Taufik, M. 2019. Characterization of Tin Oxide Doping Antimony Thin Layer With Sol-Gel Spin Coating Method for Electronic Device. Materials Science Forum, 966:30-34.

Gullu, H. H., Isik, M., Delice, S., Parlak, M., \& · Gasanly, N. M. (2020). Material and device Properties of Si-based $\mathrm{Cu}_{0.5} \mathrm{Ag}_{0.5} \mathrm{InSe}_{2}$ Thin-film Heterojunction Diode. Journal of Materials Science: Materials in Electronics, 31, 1566-1573. DOI: https://doi.org/10.1007/s10854-019-02673-3.

Hakim, S. Doyan, A., Susilawati, \& Muliyadi, L. (2019). Synthesis Thin Films $\mathrm{SnO}_{2}$ with Doping Indium by Sol-gel Spin coating. Journal of Research in 
Science Education, 5 (2), 171 -174. DOI: 10.29303/jppipa.v5i2.254.

Hegazya, A.R., Salameha, B., \& Alsmadia, A.M. (2019). Optical Transitions and Photoluminescence of Fluorine-Doped Zinc Tin Oxide Thin Films Prepared by Ultrasonic Spray Pyrolysis. Ceramics International, 45 (15), 19473-19480 DOI:https://doi.org/10.1016/j.ceramint.2019.06.204.

Ikraman, N., Doyan, A. \& Susilawati. (2017). Penumbuhan Film $\mathrm{SnO} 2$ dengan Doping Al-Zn Menggunakan Teknik Solgel Dip Coating. Jurnal Pendidikan Fisika dan Teknologi, 3(2), 228231.

DOI: http://dx.doi.org/10.29303/jpft.v3i2.415.

Imawanti, Y.D., Doyan, A. \& Gunawan, E.R. (2017). Sintesis Lapisan Tipis (Thin Film) $\mathrm{SnO}_{2}$ dan $\mathrm{SnO}_{2}$ :Al Menggunakan Teknik Sol-Gel Spin Coating pada Substrat Kaca dan Quartz. Jurnal Penelitian Pendidikan IPA, 3(1), 1-9. DOI: 10.29303/jppipa.v3i1.49.

Kendall, O., Wainer, P., Barrow, S., Embden, J.V., \& Gaspera., E.D. (2020). Fluorine-Doped Tin Oxide Colloidal Nanocrystals. Nanomaterials, 10(863), 18. DOI:10.3390/nano10050863.

Khorshidi, B., Hosseini, S.A., Ma, G., McGregor, M., Sadrzadeh, M. (2019). Novel Nanocomposite Polyethersulfone- Antimony Tin Oxide Membrane with Enhanced Thermal, Electrical and Antifouling Properties. Polymer, 163, 48-56. DOI: https://doi.org/10.1016/j.polymer.2018.12.058.

Liu L T, Liu Y, Duan X F. (2020). Graphene-based vertical thin film transistors. Sci China Inf Sci, 63(10), 1-12. DOI: 10.1007/s11432-020-2806-8.

Medhi, R., Li, C.H., Lee, S.H., Marquez, M.D., Jacobson, A.J, Lee, T.C., \& Lee, T.R. (2019). Uniformly Spherical and Monodisperse Antimony- and Zinc-Doped Tin Oxide Nanoparticles for Optical and Electronic Applications. ACS Applied Nano Materials, 2, $6554 \quad-6564$. DOI: 10.1021/acsanm.9b0147.

Muliyadi, L., Doyan, A., Susilawati, \& Hakim, S. (2019). Synthesis of $\mathrm{SnO}_{2}$ Thin Film with a Doping Fluorine by Sol-Gel Spin Coating Method. Journal of Research in Science Education, 5(2), 175-178. DOI: 10.29303/jppipa.v5i2.257.

Munandar, H., Doyan, A., \& Susilawati, S. (2020). Synthesis of $\mathrm{SnO} 2$ Thin Coatings by Indium and Aluminum Mixed Doping using the Sol-Gel Spin-Coating Technique. Journal of Research in Science Education. 6(2), 153-156. DOI: 10.29303/jppipa.v6i2.391.

Rebholz, J., Dee, C., Weimar, U., \& Barsan, N. (2015). A Self-Doping Surface Effect and Its Influence On The Sensor Performance Of Undoped $\mathrm{SnO}_{2}$
Based Gas Sensors. Procedia Engineering, 120, 83 87.

Susilawati, A. Doyan, L. Muliyadi, \& S. Hakim. (2019). Growth of Tin Oxide Thin Film by Aluminum and Fluorine Doping Using Spin Coating Sol-Gel Techniques. Journal of Research in Science Education, 6 (1), 1-4. DOI: $10.29303 /$ jppipa.v6i1.264.

Susilawati, Doyan, A., Muliyadi, L., Hakim, S., Taufik, M., \& Nazarudin. (2019). Characteristics and Optical Properties of Fluorine Doped $\mathrm{SnO}_{2}$ Thin Film Prepared by a Sol-Gel Spin Coating. Journal of Physics: Conference Series, 1397(012003), 1-8. DOI:10.1088/1742-6596/1397/1/012003.

Susilawati, Doyan, A., Muliyadi, L., Hakim, S., \& Taufik, M. (2020). The Thickness Effect to Optical Properties Of $\mathrm{SnO}_{2}$ Thin Film with Doping Fluorine. Journal of Physics: Conference Series, 1572 (012085), 1-7. DOI:10.1088/17426596/1572/1/012085. 